\title{
ANALISIS PERGESERAN MIKRO MENGGUNAKAN SENSOR SERAT OPTIK FD 620-10
}

\author{
Bayu Hadi Saputro ${ }^{1}$, Harmadi ${ }^{2}$ dan Wildian ${ }^{2}$ \\ ${ }^{1}$ Program Pascasarjana FMIPA Universitas Andalas \\ ${ }^{2}$ Departemen Fisika, FMIPA Universitas Andalas, Padang 25163 \\ ${ }^{1}$ bayu.ddice@gmail.com; ${ }^{2}$ harmadi@fmipa.unand.ac.id
}

\begin{abstract}
ABSTRAK
Telah diperoleh sensitivitas sensor serat optik untuk pengukuran pergeseran mikro. Pergeseran mikro diukur dengan menggunakan metode sensor serat optik ekstrinsik. Susunan sistem sensor serat optik terdiri dari serat optik produksi autonics tipe FD 620-10, laser dioda dengan $\lambda=$ $650 \mathrm{~nm}$, dan fotodetektor OPT101. Sensitivitas tertinggi berada pada jarak $1 \mathrm{~mm}$ sampai $2 \mathrm{~mm}$ yakni sebesar 2,506. Maksimum pengukuran pergeseran mikro yang dapat dipakai adalah $3 \mathrm{~mm}$.
\end{abstract}

Kata Kunci : serat optik, sensitivitas, pergeseran mikro

\section{PENDAHULUAN}

Serat optik merupakan sebuah media transmisi gelombang elektromagnetik yang terbuat dari bahan kaca atau plastik. Prinsip kerja dari serat optik yakni menggunakan prinsip pemantulan sempurna (total internal reflection) dengan memanfaatkan perbedaaan indeks bias antara lapisan core dan claddingnya [1]. Serat optik saat ini dikembangkan menjadi sebuah sistem sensor yang dapat mengukur berbagai besaran fisis seperti sensor getaran $[2,3]$, sensor suhu, sensor tekanan dan sebagainya. Keunggulan serat optik sebagai sensor antara lain adalah tidak kontak langsung dengan obyek pengukuran, tidak menggunakan listrik sebagai isyarat, akurasi pengukuran yang tinggi, dan ukurannya yang kecil.

Pergeseran mikro merupakan karakteristik awal untuk pengembangan sistem sensor serat optik sebagai contoh sensor getaran [2]. Selain itu, pemanfaaatan pergeseran mikro banyak digunakan pada indusri kemasan, penanggulangan bencana alam seperti longsor dan sebagainya. Penelitian tentang pergeseran mikro telah dilakukan oleh wajdi [4], namun perlu dikembangkan perlakuan lain untuk membandingkan dan mendapatkan hasil guna menambah informasi tentang pergeseran mikro.

Kemampuan serat optik untuk menangkap pantulan cahaya dengan sudut tertentu disebut dengan numerical apperture (NA). NA merupakan besaran fisis yang dimiliki oleh setiap serat optik. NA dapat dinyatakan dengan persamaan (1).

$$
N A=\sin \theta_{\text {maks }}=\sqrt{n_{1}^{2}-n_{2}^{2}}
$$

dimana $n_{1}=$ indeks bias inti serat optik dan $n_{2}=$ indeks bias cladding serat optik.

\section{METODE PENELITIAN}

Penelitian ini menggunakan metode sensor serat optik ekstrinsik yang merupakan salah satu metode dalam pengukuran pergeseran mikro. Jenis serat optik yang digunakan adalah serat optik multimode buatan Autonics dengan tipe FD 620-10. Laser sebagai sumber cahaya berwana merah dengan panjang gelombang $\lambda=650 \mathrm{~nm}$ serta daya output $10 \mathrm{~mW}$. Komponen pendukung lainnya adalah fotodetektor OPT 101, cermin, multimeter digital, dan catu daya. 
Serat optik hanya sebagai penghubung cahaya ke sistem sensing eksternal [5]. Pada sistem ini tidak dilakukan modifikasi pada struktur serat optik untuk fungsi penginderan. Pergeseran mikro dapat dijelaskan dengan konfigurasi alat yang telah dibuat pada Gambar 1.

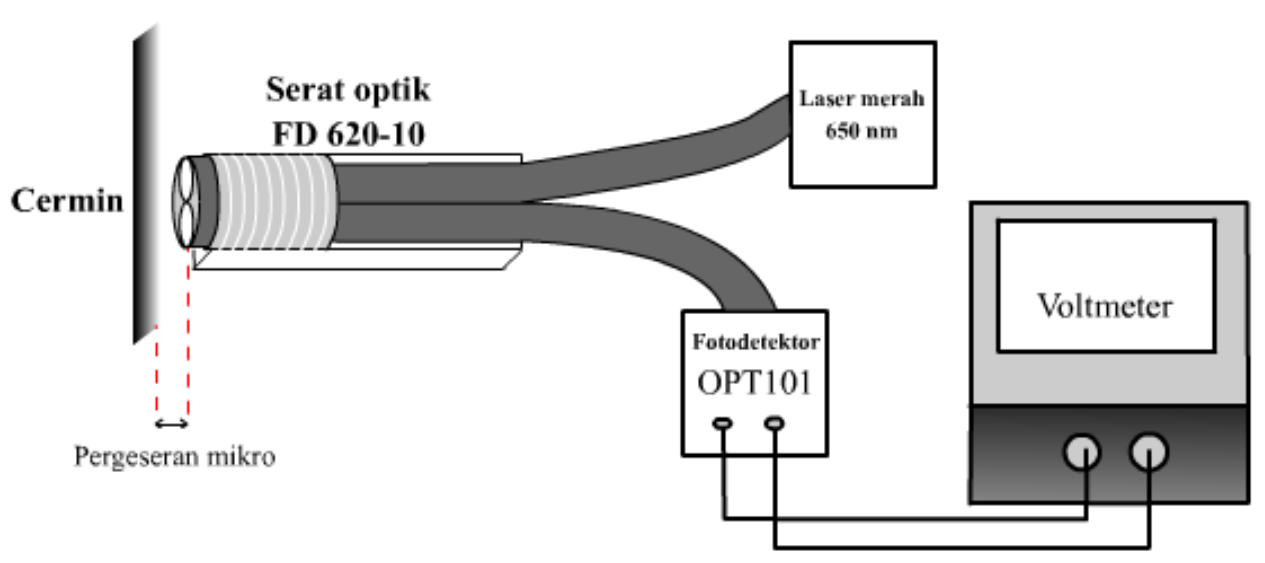

Gambar 1. Sistem sensor serat optik ekstrinsik

Serat optik yang digunakan tidak dilakukan modifikasi seperti Gambar 1. Serat optik digabungkan dengan masing-masing fungsi yakni sebagai trasmitter dan receiver. Serat optik akan mengindra pergeseran cermin berdasarkan pantulan cahaya dari cermin.

Pada Gambar 1, Cahaya dari laser merah dipandu menggunakan serat optik (transmitter) menuju cermin pemantul. Cermin pada penelitian ini dapat digeser dan memiliki ukuran penggeseran dalam orde milimeter. Cermin berfungsi sebagai pemantul cahaya dan obyek yang akan diukur posisinya. Perubahan posisi cermin menyebabkan arah cahaya yang dipantulkan akan berubah. Perubahan arah pantulan cahaya menyebabkan intensitas cahaya yang dipandu ke dalam serat optik (receiver) akan mengalami perubahan. Perubahan intensitas cahaya yang dipandu oleh serat optik (receiver) akan diubah menjadi tegangan DC oleh fotodetektor. Tegangan yang berubah akan menjadi acuan dalam menentukan perubahan posisi dari cermin dan menyatakan pergeseran mikro.

Pengukuran pergeseran mikro dilakukan dengan memvariasikan pergeseran sebesar $1 \mathrm{~mm}$ dengan rentang $0 \mathrm{~mm}$ sampai dengan $15 \mathrm{~mm}$. Pengambilan data dilakukan sebanyak 5 kali untuk memperoleh hasil yang presisi.

\section{HASIL DAN DISKUSI}

Hasil pengukuran pergeseran mikro yang telah dilakukan menggunakan serat optik di tampilkan dalam bentuk grafik pada Gambar 2 . 


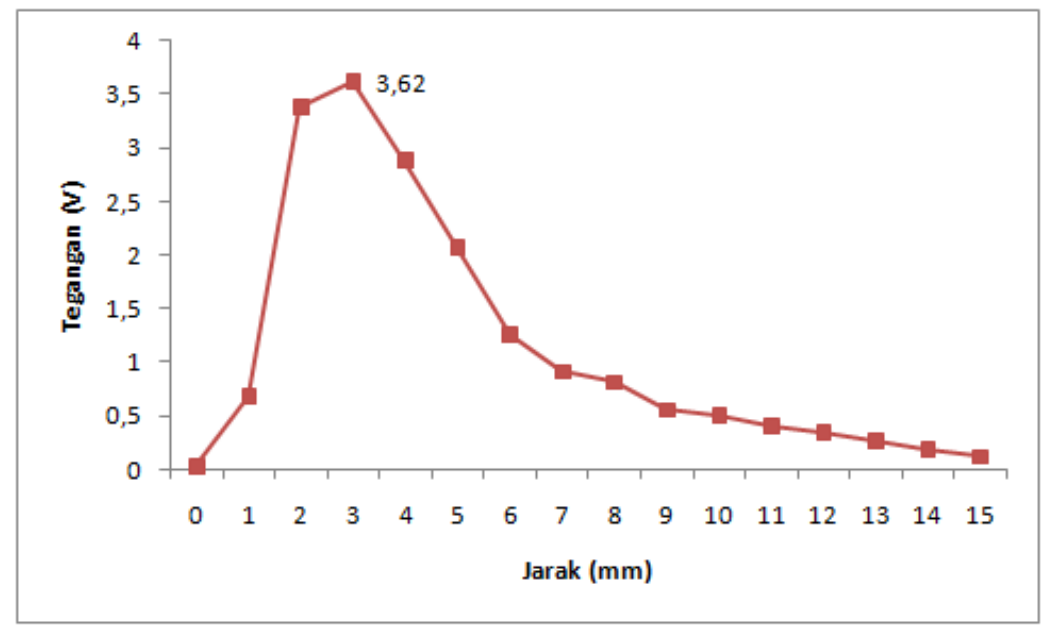

Gambar 2. Hubungan antara jarak pengukuran dan tegangan yang dihasilkan pada pengukuran pergeseran mikro

Berdasarkan kurva grafik pada Gambar 2 dapat dijelaskan bahwa perubahan posisi cermin mempengaruhi tegangan keluaran dari fotodetektor. Pada jarak $0 \mathrm{~mm}$ sampai 3 $\mathrm{mm}$ menunjukkan kecenderungan (trend) grafik meningkat, sedangkan pada jarak $3 \mathrm{~mm}$ sampai $15 \mathrm{~mm}$ menunjukkan kecenderungan grafik menurun.

Bagian pertama ketika kurva memiliki kecenderungan naik pada posisi cermin berjarak 0 $\mathrm{mm}$ sampai $3 \mathrm{~mm}$ dengan sensor serat optik. Kecenderungan ini terjadi karena sudut pantulan cahaya dari cermin dianggap masih dalam range sudut yang masih bisa diterima oleh serat optik. Kecenderungan naik didukung teori numerical apreture (NA). Secara perhitungan, sudut NA yang dimiliki oleh serat optik FD-620-10 sebesar 11,55 ${ }^{\circ}$. Jarak antara $1 \mathrm{~mm}$ sampai dengan $2 \mathrm{~mm}$ memiliki sensitivitas terbesar yakni 2,506. Hasil ini dapat digunakan sebagai acuan untuk mengembangkan sensor serat optik untuk mengukur getaran.

Bagian kedua ketika kurva memeliki kecenderungan menurun untuk jarak besar dari 3 $\mathrm{mm}$. Pada bagian ini tegangan berkurang dengan bertambahnya jarak antara cermin dengan sensor serat optik, dimana hubungan ini berkebalikan dengan kurva pada jarak 0 mm - $3 \mathrm{~mm}$. Keadaan ini terjadi diduga karena pada jarak besar dari $3 \mathrm{~mm}$ jumlah cahaya pantulan cermin hanya sedikit yang dapat masuk ke dalam serat optik. Hasil ini tidak dapat diambil sebagai acuan dalam proses pengukuran pergeseran mikro.

\section{KESIMPULAN DAN SARAN}

Hasil yang telah didapatkan dalam penelitian ini menunjukkan bahwa sensor serat optik dapat mengukur pergeseran mikro. Berdasarkan rentang pengukuran yang dilakukan mulai dari $0 \mathrm{~mm}-15 \mathrm{~mm}$, hasil terbaik pada pengukuran pergeseran mikro didapatkan pada posisi jarak $0 \mathrm{~mm}-3 \mathrm{~mm}$ antara cermin dengan serat optik. Dimana, sensitivitas tertinggi didapatkan pada jarak $1 \mathrm{~mm}-2 \mathrm{~mm}$ yang sangat potensial untuk dikembangkan untuk pembuatan sensor getaran.

Saran dari tindak lanjut penelitian ini adalah dapat dikembangkan sensor serat optik untuk pengukuran getaran. Selanjutnya dapat meningkatkan sensitivitas dari sensor serat optik dengan melakukan variasi diameter dari serat optik. 


\section{DAFTAR PUSTAKA}

[1] Udd, Eric. 1991. Fiber Optic Sensors : An introduction for engineers and scientist. John Wiley and Sons, Inc : Canada

[2] Saputro, Bayu H. 2014. Aplikasi sistem sensor serat optik untuk pengukuran frekuensi getaran akustik. Unand: Padang.

[3] Zulaichah, Siti. 2004. Pengukuran Frekuensi Getaran Menggunakan Serat Optik. ITB : Bandung.

[4] Wajdi, Badrul., Marzuki, Ahmad., Cari. 2010. Pergeseran Mikro Fiber Optik Sebagai Dasar Rancangan Sensor Pengukuran Dalam Orde Mikro. Prosiding seminar nasional teknik fisika (STNF10), Surabaya

[5] Castrellon, J. 2002. Optical Fiber Sensors: An Overview. Autonomous University of Morelos State, Meksiko. 